\title{
Effect of Tuna Skin Gelatin-Based Coating Enriched with Seaweed Extracts on the Quality of Tuna Fillets During Storage at $4{ }^{\circ} \mathrm{C}$
}

\author{
Milene Vala ${ }^{\mathrm{a}}$, Ana Augusto ${ }^{\mathrm{a}}$, André Horta $^{\mathrm{a}}$, Susana Mendes ${ }^{\mathrm{a}}$, And Maria M. \\ $\mathrm{GIL}^{\mathrm{a}^{*}}$ \\ ${ }^{\text {a }}$ MARE - Marine and Environmental Sciences Centre, ESTM, Polytechnic Institute of Leiria, Portugal \\ - These authors contributed equally to this work \\ ${ }^{*}$ Corresponding author \\ maria.m.gil@ipleiria.pt \\ TEL: $(+351) 262783607$ \\ FAX: $(+351) 262783088$
}

Received: 21 November 2016; Published online: 18 October 2017

Invited paper from the 4th International ISEKI Food Conference - ISEKI_Food 2016 - Bridging Training and Research for Industry and the Wider Community - Responsible Research and Innovation in the Food Value

\begin{abstract}
Nowadays, consumers demand high quality food products with an extended shelf-life without chemical additives. Edible coatings (EC) containing natural compounds are a promising preservation technology for raw seafood without compromising fresh-like appeal and nutritional content.

The aim of this work was to evaluate the effect of Thunnus obesus skin gelatin-based EC containing Codium spp. or Fucus vesiculosus extracts on raw tuna preservation. Three gelatin-based EC (gelatin $(5 \%)+$ glycerol $(25 \%)$; gelatin $(5 \%)+$ Codium spp. $(1 \%)+$ glycerol $(25 \%)$; gelatin $(5 \%)+$ Fucus vesiculosus $(1 \%)+$ glycerol $(25 \%))$ were applied directly on the surface of tuna fillets. Functional properties of gelatin and gelatin-based EC containing seaweed extracts were also studied. The gelatin was extracted by an acid-swelling process in the presence/absence of pepsin, followed by subsequent heating/refrigeration, after a pre-treatment with $\mathrm{NaOH}$. The type of acid, temperature and concentration of $\mathrm{NaOH}$ greatly influence the process yield. The higher extraction yield was achieved using acetic acid in the presence of pepsin by subsequent refrigeration, especially when skins were previously treated with $\mathrm{NaOH}(0.2 \mathrm{M})$. Tuna quality was assessed over 12 days of storage at $4 \pm 1{ }^{\circ} \mathrm{C}$ in terms of chemical and microbial indices. Results showed that tuna skin gelatin-based EC avoids tuna deterioration. Microbial growth, assessed by total viable counts, and total volatile basic nitrogen were maintained below the maximum limits recommended, contrarily to the control. Additionally, the use of EC increased the stability of red colour during storage.
\end{abstract}

Keywords: Edible coating; Seaweed extract; Shelf-life; Tuna; Fish skin gelatin; Seafood

\section{Introduction}

Seafood is a valuable source of protein, fatty acids, minerals and vitamins, however is a highly perishable product, and decomposition starts immediately post-mortem, which makes these food products difficult to commercialise (Augusto, Gil, \& Silva, 2016). In Portugal, fish processing has expanded and the country has become an important exporter of fish products (Bjorndal, Brasao, Ramos, \& Tusvik, 2016). Of these exported products, common ready-to-eat 
seafood products, including smoked and salted \& dried are expanding, while canned products have been stable. Likewise, fresh tuna consumption has greatly increased and tuna fillets packed as ready-to-eat product could respond to the growing market of minimally processed food by combining quality and convenience. According to FAO (2016), the yellowfin tuna (Thunnus albacares) predominates in tropical and subtropical waters and in 2014, 1.4 MT were caught worldwide, while Thunnus obesus catches predominate in ocean Pacific and about 0.41 MT were caught in 2014 (FAO, 2016).

Due to the initial high microbial load of raw fish and the increasing global supply of safe, convenient and environmentally sustainable seafood, research for new and efficient methods or technologies of preservation makes the application and development of novel packaging solutions essential (Augusto, Gil, \& Silva, 2016).

Edible coatings (EC) can be used as an alternative to preserve fish quality for extended shelflife while maintaining safety, which is based on consumers demand for natural and safe products. By selection of suitable matrices, food quality changes by moisture transfer, oxidation processes and loss of volatile flavours or microbial growth can be reduced or even prevented (Tavassoli-Kafrani, Shekarchizadeh, \& Masoudpour-Behabadi, 2016).

Polysaccharides, proteins and lipids are widely used as biopolymers. Among these, proteinbased materials are one of the most used raw materials. Mammalian gelatin has received research attention as a biopolymer because it is an abundant product. However, its use can cause both ethical problems and health related issues because of mammalian gelatin allergies (Hosseini, Javidi, \& Rezaei, 2016). Furthermore, industry demands more sustainable solutions through the use of by-products from the food industry. Among all the protein sources, fish gelatin (FG), has gained attention as an alternative to mammalian gelatin, due to its excellent biocompatibility, biodegradability, non-toxicity and great film forming abilities (Etxabide, Uranga, Guerrero, \& de la Caba, 2017; Hosseini et al., 2016). FG can be extracted from by-products obtained from the fish industry, such as heads, skin, bones, fins, muscle pieces, scales, viscera and others, by thermal denaturation or partial hydrolysis of collagen (Huang et al., 2017). Associated with collagen thermal denaturation, is the use of pretreatments, with either acid or alkali, allowing the swelling of collagen to increase gelatin extraction. Depending on the final objective or application, it is possible to adjust gelatin properties using different $\mathrm{pH}$ and temperature ranges, and time applied during both pre-treatments and the extraction process (Ahmad et al., 2017).

Another important topic is the possibility to incorporate natural bioactive compounds, adding functionality to coatings. The excellent biocompatibility of FG means that fish gelatin-based EC properties can be improved by the incorporation of bioactive compounds such as antioxidants, antimicrobials and antifungals (Etxabide et al., 2017). Seaweeds have been reported as a valuable source of bioactive compounds, such as antioxidants and antimicrobials (Augusto, Simoes, Pedrosa, \& Silva, 2016). Nowadays, it is possible to obtain seaweeds from aquaculture throughout the year, making them a sustainable and cost effective source of natural bioactive compounds. The incorporation of seaweeds extracts with high antioxidant and antimicrobial activities into fish gelatin-based EC could be an effective alternative to extend tuna shelf-life.

The aim of this work was to compare the preservation effect of tuna (Thunnus obesus) skin gelatin-based EC with and without seaweed extracts (Codium spp. and Fucus vesiculosus) incorporation, applied directly onto fresh tuna fillets. Additionally, the yield of different extraction methods was analysed. The best extraction method was selected and the FG characterized.

\section{Materials and Methods}

\section{$2.1 \quad$ Tuna skins}

Tuna skins (Thunnus obesus), kindly provided by a Portuguese fish company Nigel (Peniche, Portugal), were used as the source of gelatin. Meat residue was removed manually and cleaned samples were washed in tap water and stored frozen at $-13{ }^{\circ} \mathrm{C}$ until use. Before use thawed tuna skins were cut into small pieces $(0.5 \mathrm{~cm} \times 0.5 \mathrm{~cm})$. 


\section{$2.2 \quad$ Fish gelatin extraction}

The gelatin was extracted according to the method of Haddar et al. (2012) and Shyni et al. (2014) with slightly modifications and the procedure is shown in Figure 1. In order to determine the optimal conditions for gelatin extraction different pre-alkali treatment conditions, acid treatment conditions and extraction conditions were studied (Table 1). The hot-washed skins $\left(40{ }^{\circ} \mathrm{C}, 10 \mathrm{~min}\right)$, were previously washed with $\mathrm{NaOH}$ solution (see Table 1), gently stirred and then washed with water (until the wash water was at neutral $\mathrm{pH}$ ), treated with acid $(1: 10, \mathrm{w} / \mathrm{v})$, with or without the presence of pepsin and continuously stirred (see Table 1). After acid treatment, the $\mathrm{pH}$ of the mixture was adjusted to 7.0 with $10 \mathrm{M} \mathrm{NaOH}$. The samples were then incubated with continuous stirring. The extracted gelatin was filtered to remove any contaminants. Then, the filtered gelatin was centrifuged at $10000 \mathrm{x}$ g for $30 \mathrm{~min}$ at $4{ }^{\circ} \mathrm{C}$ and evaporated under vacuum at $40{ }^{\circ} \mathrm{C}$. Finally, it was lyophilized and stored at $4{ }^{\circ} \mathrm{C}$ until used.

For each procedure, the yield of gelatin was calculated. Based on these results, the optimal procedure for gelatin extraction was established. Yield of gelatin was calculated from:

$$
Y \text { ield }(\%)=\frac{\text { Weight of dried gelatin }(g)}{\text { wet weight of fresh } \operatorname{skin}(g)} \times 100
$$

\subsection{Characterization of tuna skin gelatin}

\section{Chemical composition}

Moisture and ash content of the gelatin powder were determined according to Portuguese standard methods NP 2282:2009 and NP 2032:2009, respectively. The protein content was determined by Kjeldahl method according to the Portuguese standard method NP 4488:2009. A factor of 5.4 was used to convert the nitrogen value to protein (Shyni et al., 2014). All measurements were performed in triplicate.

\section{pH value}

The pH was determined according to Alfaro, Biluca, Marquetti, Tonial, and de Souza (2014). A $1 \%$ gelatin solution was prepared with distilled water at $60{ }^{\circ} \mathrm{C}$ with continuous stirring during 30 min. The $\mathrm{pH}$ was measured using a SympHony SP7CP pH meter (VWR, U.S.A) at room temperature.

\section{Colour}

The colour of the gelatines was determined according to Kaewdang and Benjakul (2015) using a Konica Minolta colorimeter (CR400; Minolta, Japan). The colour of the gelatin gel (6.67 g 100 $\mathrm{mL}^{-1}$ ) was measure in a liquid cell (CR-A504), with a white base placed on the bottom. The measurements were repeated three times for each solution.

\section{Determination of gel strength}

Gel strength was determined according to the procedure described by Haddar et al. (2012). Gelatin solution (6.67 g $100 \mathrm{~mL}^{-1}$ ) was cooling down to $7^{\circ} \mathrm{C}$ for $16-18 \mathrm{~h}$ (maturation time). Gel strength was determined with a texturometer (TA.XT.Plus, Texture Analyzer, Stable Micro Systems, England), according to the gelatin gel software application guide, "Determination of gel strength (Bloom Value) of gelatin according to the Gelatin Manufacturers Institute of America (GMIA) and Gelatin Manufacturers Europe (GME) testing standard", with a probe $0.5 "$ (P/0.5, Cylinder Probe) and a maximum speed of $1 \mathrm{~mm} \mathrm{~s}^{-1}$. The maximum force (in $\mathrm{g}$ ) was determined when the probe penetrated to a depth of $4 \mathrm{~mm}$ from the surface of the gelatin gel. The strength of the gel was expressed as the maximum force (in $\mathrm{g}$ ) required to press the plunger to deflect the gel surface by $4 \mathrm{~mm}$ without breaking it. The measurements were repeated three times for each solution. 
204 | Vala et al.

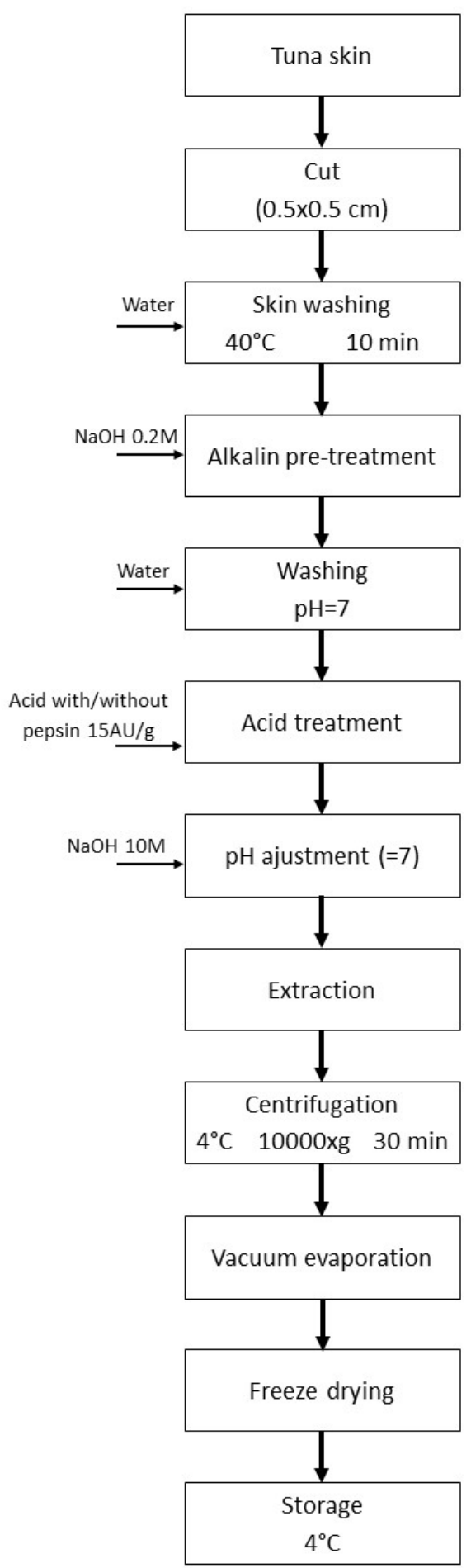

Figure 1: Flowchart of the procedure used for extraction of gelatin from fish skins.

IJFS | October 2017 | Volume 6 | pages 201-221 
Table 1: Gelatin extraction conditions. The different conditions between treatments are given in bold.

\begin{tabular}{|c|c|c|c|}
\hline Nomenclature & Alkali pre-treatment & Acid pre-treatment & Extraction \\
\hline $\mathbf{A}$ & $\begin{array}{c}\mathrm{NaOH} 0.1 \mathrm{M} \\
27 \pm 0.5^{\circ} \mathrm{C}, 1 \mathrm{~h}, \text { twice }\end{array}$ & $\begin{array}{c}\mathrm{CH}_{3} \mathrm{COOH} 0.2 \mathrm{M} \\
23 \pm 1{ }^{\circ} \mathrm{C}, 12 \mathrm{~h}, \text { twice }\end{array}$ & $45 \pm 1{ }^{\circ} \mathrm{C}, \mathrm{t}=12 \mathrm{~h}$ \\
\hline B & $\begin{array}{c}\mathrm{NaOH} 0.1 \mathrm{M} \\
27 \pm 0.5^{\circ} \mathrm{C}, 1 \mathrm{~h}, \text { twice }\end{array}$ & $\begin{array}{c}\mathrm{CH}_{3} \mathrm{COOH} 0.2 \mathrm{M} \\
\mathbf{4} \pm \mathbf{1}{ }^{\circ} \mathbf{C}, 12 \mathrm{~h}, \text { twice }\end{array}$ & $45 \pm 1{ }^{\circ} \mathrm{C}, \mathrm{t}=12 \mathrm{~h}$ \\
\hline C & $\begin{array}{c}\mathrm{NaOH} 0.1 \mathrm{M} \\
\mathbf{2 7} \pm \mathbf{0 . 5}{ }^{\circ} \mathbf{C}, \mathbf{1} \mathbf{~ h}, \text { twice }\end{array}$ & $\begin{array}{c}\mathbf{C}_{6} \mathbf{H}_{8} \mathbf{O}_{7} \mathbf{0 . 2} \mathbf{M} \\
23 \pm 1{ }^{\circ} \mathrm{C}, 12 \mathrm{~h}, \text { twice }\end{array}$ & $45 \pm 1{ }^{\circ} \mathrm{C}, \mathrm{t}=12 \mathrm{~h}$ \\
\hline D & $\begin{array}{c}\mathrm{NaOH} 0.1 \mathrm{M} \\
27 \pm 0.5^{\circ} \mathrm{C}, 1 \mathrm{~h}, \text { twice }\end{array}$ & $\begin{array}{c}\mathrm{C}_{6} \mathrm{H}_{8} \mathrm{O}_{7} 0.2 \mathrm{M} \\
\mathbf{4} \pm \mathbf{1}^{\circ} \mathbf{C}, \mathbf{1 2} \mathbf{h}, \text { twice }\end{array}$ & $45 \pm 1^{\circ} \mathrm{C}, \mathrm{t}=12 \mathrm{~h}$ \\
\hline $\mathbf{E}$ & $\begin{array}{c}\mathrm{NaOH} \mathbf{0 . 0 4} \mathrm{M} \\
27 \pm 0.5^{\circ} \mathrm{C}, 30 \mathrm{~min}\end{array}$ & $\begin{array}{c}\mathrm{H}_{2} \mathrm{SO}_{4} 0.12 \mathrm{M} ; 27 \pm 0.5{ }^{\circ} \mathrm{C}, 30 \mathrm{~min} \\
\mathrm{C}_{6} \mathrm{H}_{8} \mathrm{O}_{7} 0.005 \mathrm{M} ; 27 \pm 0.5{ }^{\circ} \mathrm{C}, 30 \mathrm{~min}\end{array}$ & $\begin{array}{l}56 \pm 1^{\circ} \mathrm{C}, \mathrm{t}=12 \mathrm{~h} \\
65 \pm 1^{\circ} \mathrm{C}, \mathrm{t}=12 \mathrm{~h}\end{array}$ \\
\hline $\mathbf{F}$ & $\begin{array}{c}\text { NaOH } 0.1 \mathrm{M} \\
27 \pm 0.5^{\circ} \mathrm{C}, 1 \mathrm{~h}, \text { twice }\end{array}$ & $\begin{array}{c}\mathrm{CH}_{3} \mathrm{COOH} 0.2 \mathrm{M}+15 \mathrm{AU} \mathrm{g}^{-1} \text { pepsin } \\
4 \pm 1^{\circ} \mathrm{C}, 12 \mathrm{~h} \text {, twice }\end{array}$ & $50 \pm 1{ }^{\circ} \mathrm{C}, \mathrm{t}=12 \mathrm{~h}$ \\
\hline G & $\begin{array}{c}\mathrm{NaOH} \mathbf{0 . 2} \mathbf{~ M} \\
27 \pm 0.5{ }^{\circ} \mathrm{C}, 1 \mathrm{~h}, \text { twice }\end{array}$ & $\begin{array}{c}\mathrm{CH}_{3} \mathrm{COOH} 0.2 \mathrm{M}+15 \mathrm{AU} \mathrm{g}^{-1} \text { pepsin } \\
\mathbf{4} \pm \mathbf{1}{ }^{\circ} \mathbf{C}, \mathbf{2 4} \mathbf{h}\end{array}$ & $50 \pm 1{ }^{\circ} \mathrm{C}, \mathbf{t}=\mathbf{1 8} \mathbf{h}$ \\
\hline
\end{tabular}

Values are presented as mean $\pm \mathrm{SD}$

\subsection{Preparation of macroalgae extracts}

\section{Codium spp. and Fucus vesiculosus}

Codium spp. samples were collected from the Abalo beach in Peniche, Portugal. Seaweeds were washed with distilled water to remove invertebrate organisms and other debris. After washing the seaweed was freeze dried, packed and conditioned at room temperature.

Dried Fucus vesiculosus were supplied by Algaplus (Portugal).

\section{Extraction method}

Seaweed extracts were prepared according to the method used by Augusto, Simoes, et al. (2016). Lyophilized seaweed ( $2 \mathrm{~g}), 22.5 \mathrm{~mL}$ of water and $7.5 \mathrm{~mL}$ of ethanol, were stirred whilst protected from light for $6 \mathrm{~h}$. After centrifugation at 2000 $\mathrm{g}$ for $10 \mathrm{~min}$, the supernatant was collected and filtered through a Büchner funnel. Extraction solutions were dried by vacuum-evaporator at 30 ${ }^{\circ} \mathrm{C}$ and freeze dried $(24 \mathrm{~h})$. The dried extracts were stored at $4{ }^{\circ} \mathrm{C}$ until further analysis.

\subsection{Coating solutions}

\section{Preparation of fish gelatin-based coating solutions}

The coating solutions were prepared dissolving gelatin (5 g $100 \mathrm{~mL}^{-1}$ water) in distilled water and adding glycerol (25 $\mathrm{g} \mathrm{G}^{-1}$ gelatin). The algae extract was incorporated $(1 \%)$ and mixed again. The treatment formulations tested were: (FG) gelatin $(5 \%)+$ glycerol $(25 \%)$, (FGC) gelatin $(5 \%)+$ Codium spp. $(1 \%)+$ glycerol $(25 \%)$, (FGF) gelatin $(5 \%)+$ Fucus vesiculosus $(1 \%)+$ glycerol $(25 \%)$. Distilled water was used as control.

\section{Fish gelatin-based coating solutions characterization}

\section{pH value}

pH was measured according to Rahman, AiSaidi, and Guizani (2008) using a SympHony SP7CP pH meter, previously calibrated.

\section{Colour}

As previously described (see 2.3.). 


\section{Total phenolic content}

Total phenolic content was determined as gallic acid equivalents (GAE) according to (Augusto, Simoes, et al., 2016), with slight modifications. To a microfuge tube were added distilled water $(158 \mu \mathrm{L}), 2 \mu \mathrm{L}$ of sample and $10 \mu \mathrm{L}$ of Folin-Ciocaulteu reagent (Merck, Germany). After 2 min $30 \mu \mathrm{l}$ of $\mathrm{Na}_{2} \mathrm{CO}_{3}$ to $20 \%$ (w/v) (Panreac, Germany) was added. After $1 \mathrm{~h}$ incubation at room temperature in the dark, the absorbance was measured at $755 \mathrm{~nm}$ (Biotek Synergy H1, US) and compared to a gallic acid calibration curve.

\section{2,2-Diphenyl-1-picrylhydrazyl (DPPH) radical-scavenging assay}

The DPPH radical-scavenging activity was assayed by the method described in Augusto, Simoes, et al. (2016) with some modifications. DPPH solution (0.1 mM) (Sigma-Aldrich, Germany) was prepared in absolute ethanol. For the final reaction $2 \mu \mathrm{L}$ of sample and 198 $\mu \mathrm{L}$ of DPPH solution were mixed. After 30 min of incubation at room temperature in the dark, absorbance was measured at $517 \mathrm{~nm}$, distilled water being used as the blank. All samples were analysed in triplicate. The DPPH radical-scavenging activity was calculated as follows:

$$
\mathrm{DPPH} \text { reduction }=\frac{A b s_{\text {Sample }}-A b s_{\text {blank }}}{A b s_{\text {control }}}
$$

where $\mathrm{Abs}_{\text {sample }}$ is sample absorvance, $\mathrm{Abs}_{\text {blanck }}$ is sample blank and $\mathrm{Abs}_{\text {control }}$ is DPPH solution absorvance.

\section{Coating application and storage}

\section{Tuna samples}

Thunnus albacares (yellowfin tuna, captured in the eastern Atlantic Centre) was kindly provided by Omnifish (Peniche, Portugal). After unpacking, tuna was cut into fillets of $1-2 \mathrm{~cm}$ of thickness and an average weight of $100 \pm 10 \mathrm{~g}$. The samples were stored at $4{ }^{\circ} \mathrm{C}$ until further use.

\section{Application of fish gelatin-based coating solutions}

Coating solutions were applied to raw tuna fillets by spraying both sides for $5 \mathrm{~s}$ each side.

The tuna were then left for 12 days at $4{ }^{\circ} \mathrm{C}$. This temperature was monitored and recorded twice a day. During storage, samples were taken in triplicate and analysed separately to assess fish quality.

\section{Microbiological analysis - total viable counts (TVC)}

Total viable counts (TVC) were estimated according to the procedure described in the standard ISO 4833:2013.

\section{Chemical analysis}

\section{Moisture content}

Moisture content of coated tuna was determined according to the Portuguese standard method NP 2282:2009.

\section{Determination of $\mathrm{pH}$}

$\mathrm{pH}$ determination was carried out according to Duan, Cherian, and Zhao (2010) with a few modifications. Approximately 5 - $10 \mathrm{~g}$ of sample was homogenized with distilled water in 1:10 (w/v). After 5 min at room temperature, $\mathrm{pH}$ was determined with Inolab $720 \mathrm{pH}$-meter (Germany). The experiments were repeated in triplicate.

\section{Colour}

As previously described (see 2.3.). Each sample was measured in nine different locations. Results were reported as whiteness index (WI, eq. 3) and total colour variations ( $\Delta \mathrm{E}$, eq. 4) (Pathare, Opara, \& Al-Said, 2013).

$$
\begin{gathered}
\mathrm{WI}=\sqrt{\left(100-L^{2}\right)+a^{* 2}+b^{* 2}} \\
\Delta E=\sqrt{\Delta a^{* 2}+\Delta b^{* 2}+\Delta L^{2}}
\end{gathered}
$$




\section{Thiobarbituric acid reactive substances (TBARS)}

Thiobarbituric acid (TBA) was determined according to the procedure described in the standard NP 3356:2009.

\section{Determination of total volatile base nitrogen (TVB-N)}

The total volatile basic nitrogen $(\mathrm{TVB}-\mathrm{N})$ value was determined according to the procedure described in the standard NP 2930:2009.

\section{Texture}

Texture analyses were performed using a TA.XT Plus texture analyser (Stable Micro Systems, England) equipped with a $30 \mathrm{~kg}$ load cell and a round needle type probe with $0.5 \mathrm{~cm}$ in diameter $(\mathrm{P} / 5 \mathrm{~S}$ Sph, Stainless). The device was set and moved perpendicularly to the sample with $5 \mathrm{~mm}$ thickness at a speed of $1.1 \mathrm{~mm} \mathrm{~s}^{-1}$. All samples were analysed in triplicate and the hardness variable (maximum force required to compress the sample) was determined (MousakhaniGanjeh, Hamdami, \& Soltanizadeh, 2015).

\section{Statical analysis}

All measurements were performed in triplicate, except when stated otherwise. One-way analysis of variance (ANOVA), followed by Dunnett's test (for comparisons to control samples) and Least Significance Difference (LSD) test for multiple comparisons of group means were applied to determine significant differences between treatments (Ct, FG, FGC and FGF). The same procedure was applied to compare days $(0,3,6,9$ and 12) (Zar, 2010). All data were checked for normality and homoscedasticity. This procedure was applied for all measurements under study. Where applicable, results were presented as mean \pm standard deviation (SD).

Principal component analysis (PCA) (Jolliffe, 2002) was used to obtain an overview of the coating effect on the physico-chemical parameters of coated tuna and stored at refrigeration temperature. The principal components (PC1 and PC2) provide information on the most meaningful parameters, which described a whole data set af- fording data reduction with the minimum loss of original information. Although the results concerning the first two components were presented, the others were also analysed. The PCA model was built on the average of the data, and full cross-validation was used to validate the model. For all statistical tests, the significance level was set at $\mathrm{p} \leq 0.05$. All calculations were performed with IBM SPSS Statistics 23. PCA was performed with CANOCO version 4.5 package (Ter Braak \& Smilauer, 1998).

\section{Results and Discussion}

\subsection{Fish gelatin extraction}

It is well known that acid type and concentration, pre-treatment time, extraction temperature and time, greatly affects gelatin yield, physical and sensory properties. It is also well known that extraction yield is of major importance to the industry because of its economic importance. Consequently, gelatin extraction yield should be considered as a key factor to select optimal extraction conditions.

Preliminary studies (Table 6, supplementary data) showed that extraction yield varied between $0.41 \%$ and $26.45 \%$ depending on the extraction conditions. The alkali and the acid pretreatments as well as the extraction time and temperature, greatly affected the process yield. The recovered FG was about 39 times higher if an alkali pre-treatment $(0.2 \mathrm{M} \mathrm{NaOH}, 27 \pm 1$ $\left.{ }^{\circ} \mathrm{C}, 2 \mathrm{~h}\right)$ followed by acid pre-treatment $(0.2 \mathrm{M}$ $\mathrm{CH}_{3} \mathrm{COOH}$ plus $15 \mathrm{AU}$ pepsin $\mathrm{g}^{-1}$ gelatin, $4 \pm 1$ ${ }^{\circ} \mathrm{C}, 24 \mathrm{~h}$ ) and a gelatin extraction at $50 \pm 0.5{ }^{\circ} \mathrm{C}$ (18 h) was selected. Nevertheless, Rahman et al. (2008) and Cho, Gu, and Kim (2005) reported higher yield values for yellowfin tuna gelatin extraction ( $57.8 \%$ and $89.7 \%$, respectively). Thus, to increase the process yield, pepsin was added during the acid treatment according to Haddar et al. (2012) and Karim and Bhat (2009). Both these groups of authors found that the addition of pepsin during the acid pre-treatment results in a higher gelatin extraction yield. Pepsin induces collagen solubilisation by negligible hydrolysis of the collagen peptides (Karim \& Bhat, 2009) and consequently higher recovery of gelatin $(26.45 \pm$ 
$2.83 \%$ ). In this study the addition of pepsin to the process led to an improvement of the extraction yield (increase $50 \%$ ), compared to extraction process without pepsin $(0.41 \%$ to 10.28 $\%)$. The fish gelatin obtained with the highest extraction yield was considered for further work.

\subsection{Gelatin and coating solutions characterization}

\section{Gelatin characterization}

The quality of gelatin depends on its physicochemical properties, which are greatly influenced, not only by the origin of raw material, but also by the processing method and parameters. Therefore, FG characterization (both in terms of chemical and physical characteristics) is essential, since it allows determine of the applicability, functionality and commercial value of this type of product. Table 2 shows the results of proximate composition and physical properties of extracted FG.

A low value for protein content $(42.26 \pm 0.57 \mathrm{~g}$ $100 \mathrm{~g}^{-1}$ ) (Table 2) was obtained when compared to results obtained by Haddar et al. (2012) and

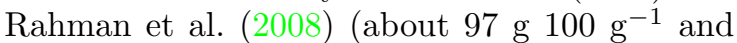

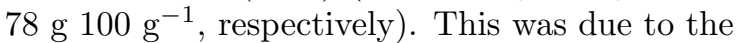
loss of extracted collagen through leaching processes during washing steps, incomplete collagen hydrolysis or protein denaturation during gelatin extraction (Rahman et al., 2008).

Gel strength is the second most important attribute of gelatin because it determines its quality. A high gel strength value indicates a good quality gelatin product (desirable values between 250 - 260). In this work, and as a consequence of low FG protein, the gel strength value was low (148.2 $\pm 5.00 \mathrm{~g}$; Table 2). A comparable range of gel strength values between 656 - 151 (g) were reported by Ahmad et al. (2017) on FG extracted from skin of Asian seabass (Lates calcarife), dover sole (Solea vulgaris) and unicorn leatherjacket (Alutherus monoceros) at temperatures between $43{ }^{\circ} \mathrm{C}$ and $70{ }^{\circ} \mathrm{C}$. Cho et al. (2005) also verified lower strength values for tuna skin FG extracted at $54^{\circ} \mathrm{C}$, with an increase of $24 \%$ in strength values when extractions were performed at $40{ }^{\circ} \mathrm{C}$. Also, according to Sinthusamran, Ben- jakul, and Kishimura (2014), if a high extraction temperature is used, low-molecular proteins from fish skin will be extracted which explains our results (Table 2). Gudmundsson and Hafsteinsson (1997) also suggested that gel strength might depend on $\mathrm{pH}$. More compact and stiffer gels are formed by adjusting the $\mathrm{pH}$ of the gelatin close to its isoelectric point, where the protein chains will be more neutral and thus the gelatin polymers are closer to each other. In this work, after acid treatment, samples were neutralized to $\mathrm{pH}$ closer to $7(\mathrm{pH}=6.69 \pm 0.01$; Table 2$)$. Similar pH values were also used by Haddar et al. (2012), for tuna skin gelatin extraction studies.

The maximum ash content is often specified, yet not indispensable, except to indicate the calcium content, which is important information for some applications. Besides this, it can be also an indicator of gelatin quality. Ash content value (1.36 $\pm 0.07 \%$; Table 2) was consistent with the literature, being the maximum recommended for gelatin of $2.6 \%$ (Ahmad et al., 2017; Haddar et al., 2012). The lower value of ash content obtained suggests that the extracted gelatin was of high quality. Nevertheless, in order to obtain lower ash content an appropriate demineralization of the fish skins could have been accomplished prior to gelatin extraction.

In general, food colour should remain unaltered upon the addition of coating solutions. If a gelatin-based coating for food packaging application is the final goal, the colour of extracted gelatin must be assessed. FG colour parameters are presented in Table 2. According to Ahmad et al. (2017), gelatins extracted at $45{ }^{\circ} \mathrm{C}$ (mid temperatures) are expected to have low $\mathrm{a}^{*}$ and $b^{*}$ values and high values of $\mathrm{L}^{*}$. In this work, low $\mathrm{L}^{*}$ values and high $\mathrm{a}^{*}$ values were obtained for the extracted gelatin. This indicated that the colour of extracted gelatin was less brightness but more redness compared to gelatins obtained by Ahmad et al. (2017).

\section{Gelatin characterization}

In order to maximize the preservative effect of FG, when applied to fresh tuna fillets, seaweed extracts were added to coating formulations. Fucus vesiculosus was chosen based on previous studies that reported high antioxidant 
Table 2: Proximate composition and physical characteristics of extracted fish gelatin.

\begin{tabular}{|c|c|c|}
\hline \multicolumn{3}{|c|}{ Gelatin } \\
\hline \multicolumn{2}{|c|}{ Moisture (\%) } & $4.41 \pm 0.15$ \\
\hline \multicolumn{2}{|c|}{ Protein (\%) } & $42.26 \pm 0.57$ \\
\hline \multicolumn{2}{|c|}{$\operatorname{Ash}(\%)$} & $1.36 \pm 0.07$ \\
\hline \multirow[t]{2}{*}{ pH } & & $6.69 \pm 0.01$ \\
\hline & $\mathbf{L}^{*}$ & $25.08 \pm 0.52$ \\
\hline \multirow[t]{2}{*}{ Colour } & $a^{*}$ & $1.51 \pm 0.08$ \\
\hline & $\mathrm{b}^{*}$ & $15.91 \pm 0.19$ \\
\hline \multicolumn{2}{|c|}{ Gel strength (g) } & $148.2 \pm 5.00$ \\
\hline
\end{tabular}

Values are presented as mean $\pm \mathrm{SD}(\mathrm{n}=3)$

and high antimicrobial activities (Pinteus et al., 2015, 2017). Codium spp. was chosen based on the work reported by Augusto, Simoes, et al. (2016) that demonstrate the preservative effect of Codium tomentosum extract as post-harvest treatment of minimally processed apples. The percentage of seaweed extracts was chosen based on a previous study, were Nowzari, Shabanpour, and Ojagh (2013) add $1 \%$ of chitosan to FG, to understand the effect of chitosan as a antimicrobial agent on the quality of refrigerated rainbow trout.

Thus, in the present study three distinct coating formulations were studied: $5 \%(\mathrm{w} / \mathrm{v})$ fish gelatin (FG), $5 \%(\mathrm{w} / \mathrm{v})$ fish gelatin with $1 \%(\mathrm{w} / \mathrm{v})$ Codium spp. extract (FGC) and $1 \%(\mathrm{w} / \mathrm{v}) \mathrm{Fu}$ cus vesiculosus (FGF) extracts. Glycerol was only added as a plasticizer. Each formulated coating solution was evaluated in terms of chemical and colour parameters before application in fresh tuna fillets. Chemical characterization, in terms of $\mathrm{pH}, \mathrm{DPPH}$, total phenol content and colour, are shown in Table 3 . In relation to $\mathrm{pH}$ values, it was observed that the incorporation of seaweed extract led to a decrease in the $\mathrm{pH}$ value of coating solutions (ANOVA, LSD test; p < 0.05) (Table 3). Despite of the lack information about optimal $\mathrm{pH}$ values for $\mathrm{EC}$, it is expected that lower $\mathrm{pH}$ values allow high food preservation which is associated with microbial inhibition and enzyme inactivation (Augusto, Gil, \& Silva, 2016).

DPPH and total phenol content of coating solutions are expressed in Table 3. The free radi- cal scavenging activity of solutions was evaluated by the decrease in the peak area of the DPPH radical. Solutions containing Fucus vesiculosus extract (FGF), showed higher total phenol content and DPPH radical-scavenging activity when compared with solutions without seaweed extracts (FG) or solutions containing Codium spp. extract (FGC) (ANOVA, LSD test; p < 0.05). These results were consistent with the literature, where Fucus sp. is known to be a source of natural antioxidants and polyphenols (Pinteus et al., 2017; Wang et al., 2012), while Codium spp. is known to be poor in antioxidant activity and polyphenol content (Augusto, Simoes, et al., 2016; Pinteus et al., 2017). The antioxidant activity of the FG solution could be explained by the peptide fraction of the fish gelatin (Haddar et al., 2012).

Colour parameters were also influenced by the incorporation of seaweed extracts (Table 3) (ANOVA, LSD test; $\mathrm{p}<0.05$ ). Unrefined seaweed extracts were used containing pigments and proteins that give colour to the EC solutions (Blanco-Pascual, Montero, \& GomezGuillen, 2014). Incorporation of seaweed extracts led to a decrease of $\mathrm{L}^{*}$ and an increase of $\mathrm{a}^{*}$ values for both FGC and FGF coatings solutions. A decrease of $\mathrm{b}^{*}$ values in $\mathrm{FG}$ with $F$. vesiculosus extract addition was also observed, indicating a decline of the lightness and redness to the FGC and FGF when compared to FG coating solutions. Interestingly, the colour parameters of FG coating solutions did not present any considerable differences when compared with FG colour (Table 2).

\subsection{Effect of fish gelatin-based coatings (with seaweed extract) on shelf-life of Tuna (Thunnus albacares)}

The fish gelatin-based edible coatings (FG, FGG and FGC) that were developed were applied directly on the surface of fresh tuna fillets. Solutions were applied by a spraying method because of the low gel strength and protein content. These FG characteristics resulted in a low viscosity coating solution which could be easily sprayed onto the food matrix (Tavassoli-Kafrani 
Table 3: Results of characterization of coating solutions formulated with fish gelatin (FG), fish gelatin with Codium spp. (FGC) and F. vesiculosus (FGF) extract, in terms of $\mathrm{pH}, \mathrm{DPPH}$, total phenol content and colour.

\begin{tabular}{|c|c|c|c|c|c|c|}
\hline & \multirow[b]{2}{*}{$\mathrm{pH}$} & \multirow{2}{*}{$\begin{array}{c}\text { DPPH } \\
\left(100 \mathrm{mg} \mathrm{mL}^{-1}\right)\end{array}$} & \multirow{2}{*}{$\begin{array}{l}\text { Total phenol content } \\
\qquad\left(100 \mathrm{mg} \mathrm{mL}^{-1}\right)\end{array}$} & \multicolumn{3}{|c|}{ Colour } \\
\hline & & & & $\mathrm{L}^{*}$ & $\mathrm{a}^{*}$ & $\mathrm{~b}^{*}$ \\
\hline FG & $6.74 \pm 0.01$ & $1.37 \pm 0.82$ & $0.031 \pm 0.008$ & $27.88 \pm 0.14$ & $-0.28 \pm 0.02$ & $16.54 \pm 0.13$ \\
\hline FGC & $6.64 \pm 0.01 \dagger$ & $1.51 \pm 0.45$ & $0.031 \pm 0.008$ & $24.16 \pm 0.15 \dagger$ & $0.18 \pm 0.03 \dagger$ & $16.30 \pm 0.25$ \\
\hline FGF & $6.55 \pm 0.01 \dagger \#$ & $2.56 \pm 0.70$ & $0.079 \pm 0.015 \dagger \#$ & $16.81 \pm 0.21 \dagger \#$ & $0.35 \pm 0.05 \dagger \#$ & $6.58 \pm 0.25 \dagger \#$ \\
\hline
\end{tabular}

Values are presented as mean $\pm \mathrm{SD}(\mathrm{n}=3)$. $\dagger \mathrm{FG}$; \#FGC, the mean difference is significant at the 0.05 level (that is, $\mathrm{p}<0.05$. ANOVA, LSD test).

et al., 2016). Tuna quality was assessed over 12 days of storage at $4 \pm 1{ }^{\circ} \mathrm{C}$ in terms of chemical and microbial indices.

\section{Total viable counts}

Microbial activity is one of the limiting factor on the shelf life of fresh fish, being the total viable counts (TVC) usually used as an acceptability index in standards, guidelines and specifications (Olafsdottir et al., 1997).

The initial total viable count (TVC) value for raw tuna was $3.15 \pm 0.13 \log _{10} \mathrm{CFU} \mathrm{g}^{-1}$ (within the normal range given that they were kindly provided by Omnifish and hence were subject to handling during preparation of the fillets) and the evolution of this index during storage is shown in Fig. 2. The TVC for each of the coated tuna fillets were different according to the coating solutions. In fact, despite all four batches following similar trends with the special step at day 9 of refrigerated storage (ANOVA, LSD test; $\mathrm{p}<0.05$ ), coating inhibited microbial growth to a certain extent. Additionally, the microbiological growth rate in control samples seemed to be higher than in the other three groups during the storage period. There was a difference of around $2 \log$ cycles between the control and the coated batches (Fig. 2) at 9 - 12 days of storage and the microbiological limit of $7 \log _{10} \mathrm{CFU}$ $\mathrm{g}^{-1}$ for raw fish of good quality was exceeded at 9 days $\left(7.58 \pm 2.0 \log _{10} \mathrm{CFU} \mathrm{g}{ }^{-1}\right)$ ( $\mathrm{Li}$ et al., 2012). Furthermore, samples coated with FG and with FGC also exceeded the limit value at day $12\left(7.11 \pm 0.44 \log _{10} \mathrm{CFU} \mathrm{g}^{-1}\right)$. In this particular case, there was evidence that the type of coating applied influenced the microbial growth.
Samples coated with FG and seaweed extracts (FGC and FGF) did not reach the limit values of TVC until the end of the storage period, presenting lower values on day 12 , when compared with the control treatment (ANOVA, LSD test; $\mathrm{p}$ $<0.05$ ). The presence of antimicrobial oligopeptide chains that are formed with collagen hydrolysis could explain the antimicrobial activity of FG coatings (Nowzari et al., 2013). Furthermore, the presence of the Codium spp. extract seemed to inhibit growth of TVC very slightly, compared to the presence of the $F$. vesiculosus extract. These results were consistent with the literature, where higher antimicrobial activity in Fucus spiralis and lower values in Codium tomentosum are reported (Wahidi, Amraoui, Amraoui, \& Bamhaoud, 2015; Pinteus et al., 2015).

\section{Chemical variations}

Moisture content variation (\%) of tuna fillet during storage at $4{ }^{\circ} \mathrm{C}$ for 12 days is shown in Table 4. Results showed a decreasing trend in moisture content during the storage period (Table 7, supplementary data), although significant differences were not observed between samples bearing different coatings (ANOVA, Dunnett's test; $\mathrm{p}>0.05)$. It was expected to verify differences in moisture variation between control and coated samples, due to high protein content of FG films (which were supposed to act as a good oxygen barrier), preventing water vapour evaporating and consequently product loss moisture (Hosseini et al., 2016). However, in this specific case, the lack of protective effect in moisture loss of the extracted FG was explained by the low protein content observed (Table 2). 


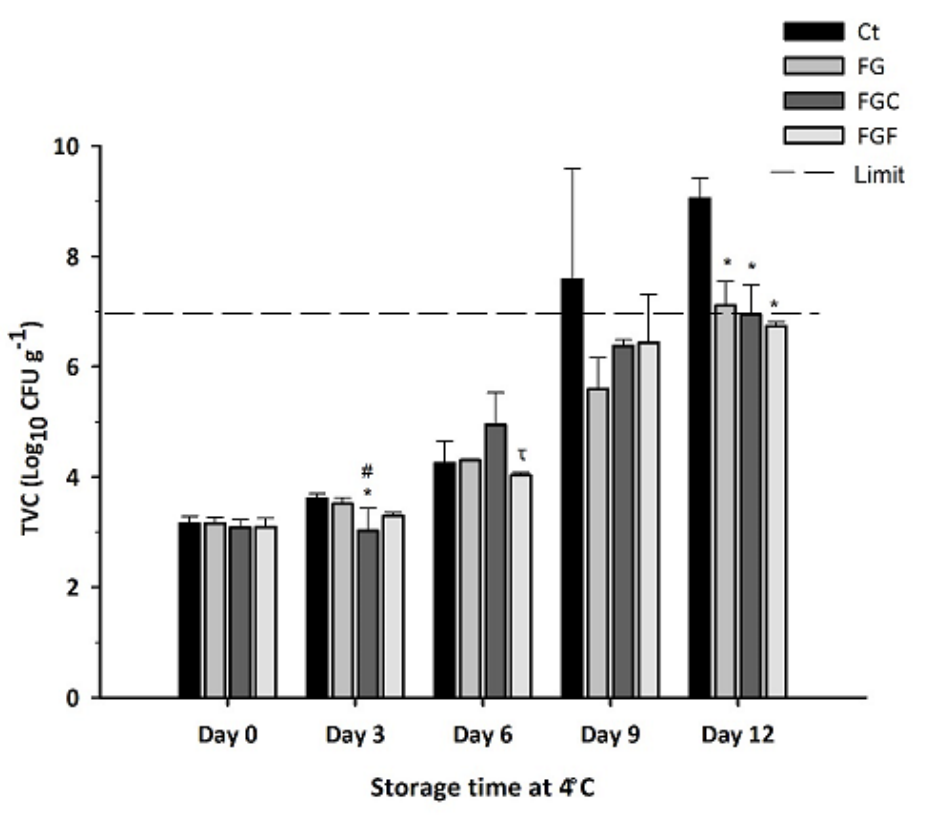

Figure 2: Total viable counts $\left(\log _{10} \mathrm{CFU} \mathrm{g}^{-1}\right)$ for tuna samples of control $(\mathrm{Ct})$ and coated with fish gelatin (FG), fish gelatin with Codium spp. (FGC) and F. vesiculosus (FGF) extracts solutions, during 12 days of storage at $4^{\circ} \mathrm{C}$. Each bar represents the mean $\pm \mathrm{SD}(\mathrm{n}=3)$. Statistically significant differences compared to samples with and without treatment in the same time (that is, $\mathrm{p}<0.05$, ANOVA, LSD test) *control; \#FG; $\tau$ FGC; and \&FGF.

Table 4: Physicochemical variations values (\%) for tuna samples between day 0 and 12 of storage at $4{ }^{\circ} \mathrm{C}$ ( (control (Ct) and coated with fish gelatin (FG), fish gelatin with Codium spp. (FGC) and $F$. vesiculosus (FGF) extracts solutions), in terms of moisture variation, $\mathrm{pH}$ variation and thiobarbituric acid ratio (TBA).TBA ratio of tuna fillets between the initial time of storage and the end.

\begin{tabular}{cccc}
\hline & Moisture variation (\%) & pH variation (\%) & TBA Ratio \\
\hline Ct & $-9.18 \pm 7.96$ & $4.95 \pm 2.07$ & $6.32 \pm 0.28$ \\
FG & $-11.98 \pm 2.95$ & $-0.41^{*} \pm 1.12$ & $4.78 \pm 1.82$ \\
FGC & $-4.52 \pm 3.65$ & $-0.90^{*} \pm 1.31$ & $6.23 \pm 0.71$ \\
FGF & $-4.23 \pm 2.93$ & $-1.83^{*} \pm 0.99$ & $4.20 \pm 1.12$ \\
\hline
\end{tabular}

Values are presented as mean $\pm \mathrm{SD}(\mathrm{n}=3)$. ${ }^{*}$ The mean difference is significant at the 0.05 level (that is, $\mathrm{p}<0.05$, ANOVA, Dunnett's test). 


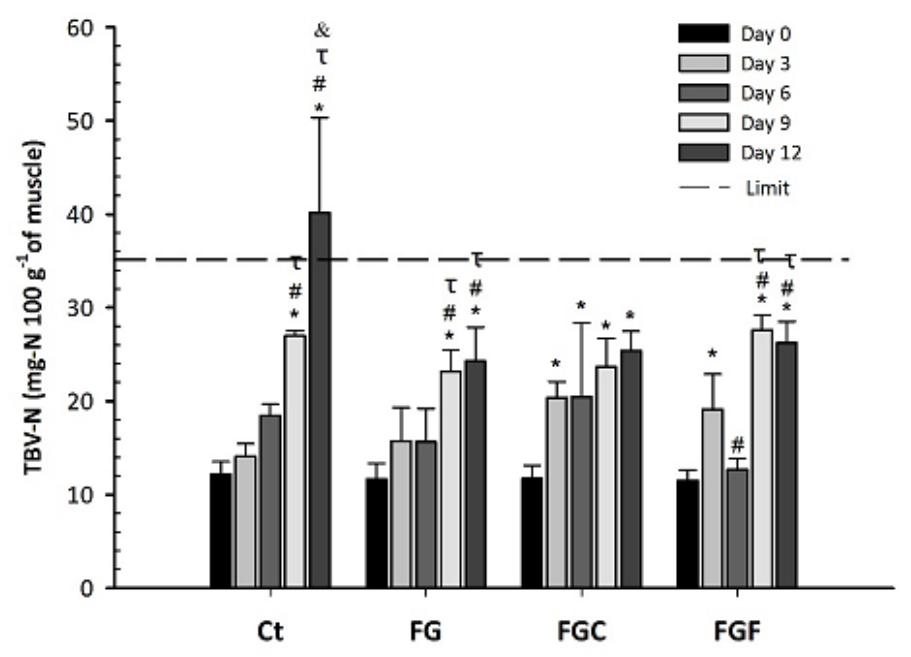

Figure 3: Total volatile basic nitrogen (TVB-N) values for tuna samples of control (Ct) and coated with fish gelatin (FG), fish gelatin with Codium spp. (FGC) and F. vesiculosus (FGF) extracts during 12 days of storage at $4{ }^{\circ} \mathrm{C}$. Each bar represents the mean \pm SD. Statistically significant differences compared to days in samples with and without treatment: *day 0; \#day $3 ; \tau$ day 6 ; and \&day 9 (that is, p $<0.05$. ANOVA, LSD test).

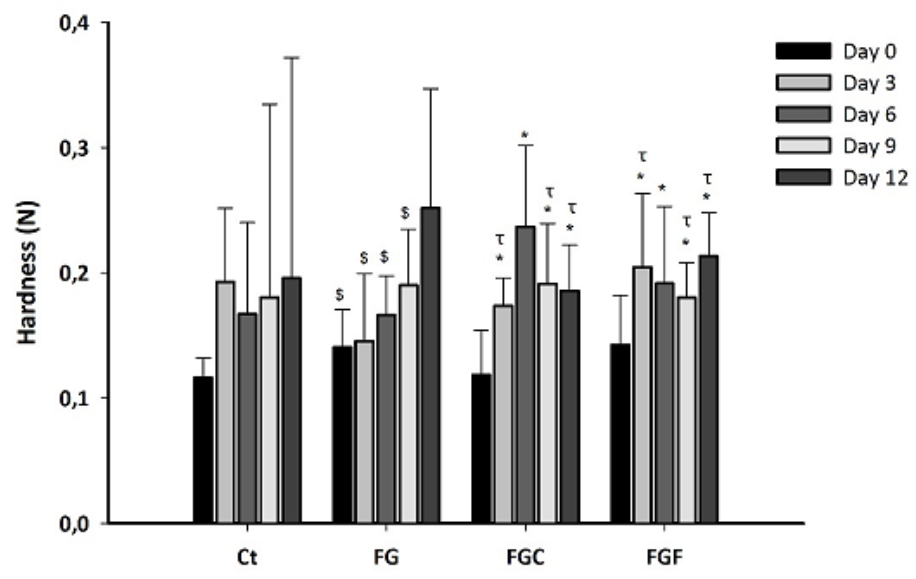

Figure 4: Hardness values (N) for tuna samples of control $(\mathrm{Ct})$ and coated with fish gelatin (FG), fish gelatin with Codium spp. (FGC) and F. vesiculosus (FGF) extracts solutions during 12 days of storage at $4{ }^{\circ} \mathrm{C}$. Each bar represents the mean \pm SD. Statistically significant differences compared to days in samples with and without treatment: *day 0; $\tau$ day 6; and $\$$ day12 (that is, $\mathrm{p}<0.05$. ANOVA, LSD test). 
Table 5: Colour parameters for tuna samples of control (Ct) and coated with fish gelatin (FG), fish gelatin with Codium spp. (FGC) and F. vesiculosus (FGF) extract solutions, in terms of whiteness index $(\mathrm{WI})$, colour differences $(\Delta \mathrm{E})$ and visual evolution of tuna fillets at day 0 and 12 .

\begin{tabular}{|c|c|c|c|c|c|}
\hline & WI day 0 & WI day 12 & $\Delta \mathrm{E}_{\text {(day 0-day } 12)}$ & Day 0 & Day 12 \\
\hline $\mathrm{Ct}$ & $34.49 \pm 6.24$ & $30.48 \pm 8.63$ & $10.04 \pm 3.68$ & & \\
\hline FG & $37.01 \pm 5.90$ & $35.57 \pm 11.11$ & $11.80 \pm 3.00$ & & \\
\hline FGC & $32.02 \pm 2.21$ & $27.16 \pm 4.20$ & $8.86 \pm 4.69$ & & \\
\hline FGF & $34.48 \pm 2.96$ & $33.11 \pm 3.09$ & $8.36 \pm 1.51$ & & \\
\hline
\end{tabular}

Values are presented as mean $\pm \mathrm{SD}(\mathrm{n}=12)$.

The $\mathrm{pH}$ value is commonly used as an indicator to determine raw seafood product freshness level as it starts with low reading at the early stage of storage and then increases when the fish has been stored for certain period of time (Ghaly, Dave, Budge, \& Brooks, 2010). Prior to storage the $\mathrm{pH}$ value ranged from $\mathrm{pH} 5.74$ to pH 5.83 (Table 7, supplementary data), which was slightly higher than values reported by Torrieri et al. (2011). The pH of fresh fish fillet is almost neutral but in the post-mortem period, decomposition of nitrogenous compounds (which are derived from microbial activity) leads to an increase in $\mathrm{pH}$ which affects the quality of the product during storage (Miranda, Trigo, Barros-Velazquez, \& Aubourg, 2016). However, initially a decrease was be observed in the fish muscle, which was attributed to $\mathrm{CO}_{2}$ dissolution in fish sample (observed in coated samples) ( $\mathrm{Li}$ et al., 2012).
Table 4 shows the $\mathrm{pH}$ variation for tuna fillets during the storage period. Different patterns were observed for all samples. Control samples (Ct) showed the highest $\mathrm{pH}$ variation (ANOVA, Dunnett's test; $\mathrm{p}<0.05)$ when compared with the samples coated with FG with and without seaweed extract incorporation. Coated samples (FG, FGC, FGF) reached a lower $\mathrm{pH}$ value when compared with control samples (ANOVA, Dunnett's test; $\mathrm{p}<0.05)$, meaning a preservation effect of coating solutions. There seemed to be evidence that the presence of coating reduced the atmosphere exposition and protected tuna from the spoiling action of the oxygen (which is known to increase the $\mathrm{pH}$ value likely a consequence of the basic amines production, as referred).

Thiobarbituric acid reactive substances (TBARS) assay is one of the most widely used indices of food quality as a critical in- 
214 | Vala et al.

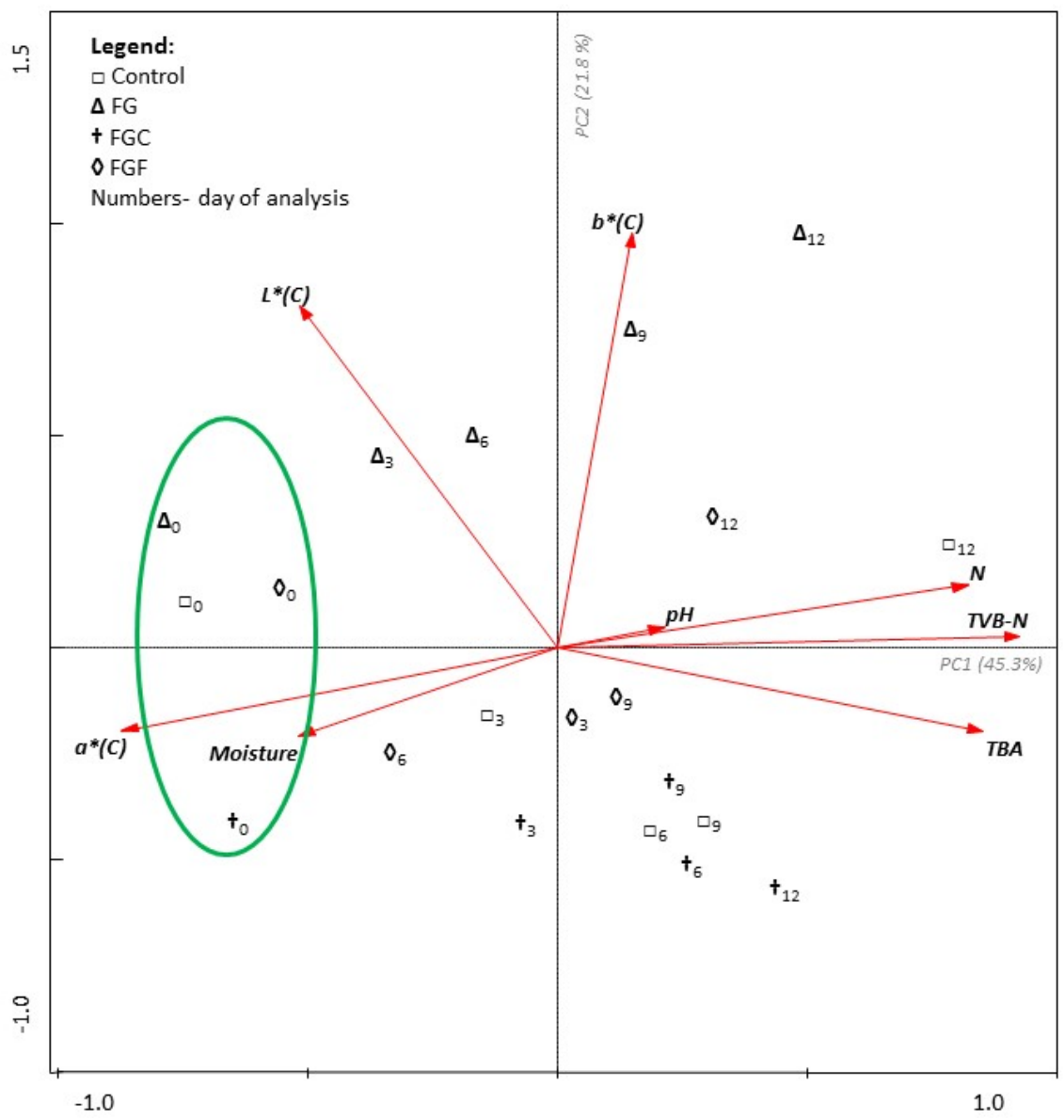

Figure 5: Biplot from principal component analysis (PCA) for chemical and physical parameters in fresh tuna coated with fish gelatin (FG), fish gelatin with Codium spp. extract (FGC) and fish gelatin with F. vesiculosus $(\mathrm{FGF})$ at different times of storage $(0,3,6,9$ and 12 days).

dex in lipid oxidation (Torrieri et al., 2011). Malondialdehyde (MDA) formed through hydroperoxides, which are the initial reaction product of polyunsaturated fatty acids with oxygen, becomes the major spoilage factor and particularly important for shelf life of raw fish. In this study, all samples (at time zero) showed lower values of thiobarbituric acid (TBA) (1.31 $\pm 0.47 \mathrm{TBA}$ ) than the proposed limits of TBA (5 $\mathrm{mg}$ of malonaldehyde equivalents $\mathrm{kg}-1$ of tissue) (Ojagh, Rezaei, Razavi, \& Hosseini, 2010).

It was also observed that, TBA greatly increased during the 6 day storage in all samples (ANOVA,
LSD test; $\mathrm{p}<0.05$ ) (Table 7 , supplementary data). These results indicated that, although the gelatin coating should reduce lipid oxidation because of the hydrogen bonds acting as a barrier to oxygen, application of a gelatin coat was not enough as a barrier to reduce lipid oxidation (Nowzari et al., 2013).

TBA ratio of tuna fillets between the initial time of storage and the end is presented in Table 4. Comparison among samples coated with different solutions and control samples provided only slight differences and there were no statistically significant differences (ANOVA, Dunnett's test; $\mathrm{p}>0.05)$. Previous studies 
have found that gelatin coating has no effect on lipid oxidation in refrigerated salmon which may be due to a temperature effect (Antoniewski, Barringer, Knipe, \& Zerby, 2007). Nowzari et al. (2013) found that rainbow trout coated with gelatin based films and stored refrigerated for 16 days has lower TBARS values than controls. However, Lopez-Caballero, Gomez-Guillen, Perez-Mateos, and Montero (2005) observed that gelatin coatings have no influence on lipid oxidation of cod fillets stored at $2{ }^{\circ} \mathrm{C}$ for 15 days. Besides this, in the present work, for coated samples with FGF it seemed that the increase was generally smaller (results not showed), however, there were no statistically significant differences (ANOVA, LSD test; $p$ > $0.05)$ supporting that conclusion. The protective effect of FGF was more pronounced, perhaps due to its antioxidant properties reported by Pinteus et al. (2017).

According to Nowzari et al. (2013), total volatile basic nitrogen (TVB-N) should be also considered as a quality index for fresh fish. This index allows us to evaluate the activity of spoilage bacteria and endogenous enzymes, by the presence of ammonia, monoethylamine, dimethylamine, trimethylamine, and other volatile bases originated from bacterial catabolism of amino acids in fish muscle ( $\mathrm{Li}$ et al., 2012). The TVB-N values for the 12 days analysed are presented in Fig. 3. The initial values of TVB-N content were higher than those expected for fresh fish, however high values of TVB-N are regularly observed for pelagic fish (Silbande et al., 2016). Despite the initial high values of TVB-N, according to Silbande et al. (2016) all samples were below the acceptability limits (30 - $35 \mathrm{mg}-\mathrm{N} 100 \mathrm{~g}^{-1}$ of muscle), indicating initial good state of tuna preservation. After twelve days of storage, all samples presented a progressive increase in TVB-N values (ANOVA, LSD test; $\mathrm{p}<0.05$ ) (Fig. 3). Such increase may be due to the activity of microbial spoilage and endogenous enzymes. In fact, the highest increase of TVB-N values was observed at day 9 for all samples, with exception of FG with Codium spp. coating (ANOVA, LSD test; p < 0.05), indicating that Codium spp. extract was effective in reducing microbial and enzymatic activities to acceptable levels. Moreover, it was observed that at the ending of storage $(12 \mathrm{~d})$ the recommended limits were reached only by the control samples (Table 8, supplementary data). These results indicated that fish gelatin based coating with and without seaweeds extracts lowered TVB-N values distinctly and hence slowed down the spoilage, which is according to microbial behaviour (Fig. 2). In fact TVB-N content and microbiological growth were in agreement and did not corroborate the results reported by Silbande et al. (2016) that indicate the inefficacy of TVB-N results as a reliable quality index of tuna.

\section{Chemical variations}

Raw tuna colour affects consumer behaviour in respect to purchase intention, once they associate tuna colour with freshness and quality (Mousakhani-Ganjeh et al., 2015). When oxymyoglobin (red) is oxidized to metmyoglobin (brown) consumers tend to reject tuna. Consequently, colour should be considered a major characteristic to take into consideration in relation to quality assessment of raw tuna. Oxygen is a promoter of oxidation, so if the presence of oxygen is eliminated or reduced, the colour of fresh tuna can be maintained.

Colour changes of coated tuna are represented by $\Delta \mathrm{E}$ (colour differences between day 0 and day 12) and whiteness index (WI at days 0 and 12) (Table 5). No statistical differences (ANOVA, LSD test; $\mathrm{p}>0.05$ ) were obtained for $\Delta \mathrm{E}$ or WI during storage and between samples. However, a tendency was observed for both $\Delta \mathrm{E}$ and WI values for samples coated with FGF. F. vesiculosus extract incorporation to have a smaller colour variation and a smaller loss of WI (at the ending of storage time) when compared to other samples. This was attributed to polyphenols, present in $F$. vesiculosus (Table 3 ) which can prevent lipid oxidation (lower TBARS ratio, Table 4), very common in tuna because of its high fat content (Mousakhani-Ganjeh et al., 2015). Photos of fresh tuna corroborated these results at day 0 and day 12 (Table 5). 


\section{Texture variations}

The first sensory changes of fish during storage are concerned with appearance and texture. Additionally, consumer's perception of the quality of fish meat is commonly influenced by texture. So, in this study the impact of coating solutions on the texture of tuna fillets was assessed, represented by fish hardness $(\mathrm{N})$, where higher values of hardness indicate greater stiffness of fish fillets.

Figure 4 shows sample hardness over 12 days, showing that all coated samples had a significant increase of hardness (ANOVA, LSD test; $p$ $<0.05$ ). Normally, fresh fish meat loses texture firmness because of microbiological and chemical changes that occur during storage (Augusto, Gil, \& Silva, 2016). However, it is difficult to control or estimate the myofibrillar protein of fish denaturation (aggregation and/or hydrolysis) which can explain the increase of firmness values (Mousakhani-Ganjeh et al., 2015). Associated with the possible protein denaturation could be the loss of moisture observed at the end of the storage period (Table ??

Finally, to assess which factors were the most important to determine the product quality, as well as to clarify the differences between the tested ECs, a Principal Component Analysis (PCA) was performed (Fig. 5).

The results showed that principal component 1 (PC 1) and 2 (PC 2) accounted for $67.1 \%$ of the total variance, being $45.3 \%$ explained by axis 1 (PC 1) (Fig. 5).

Concerning to $\mathrm{PC} 1$, it was possible to observe that treatments (Ct, FG, FGC and FGF) presented characteristics of fresh tuna at day 0 (Fig. 5, green cluster) (Nowzari et al., 2013). Moreover, TBV-N and TBA (two chemical indicators of food quality (Nowzari et al., 2013)) presented a similar pattern. Thus, with the increase of storage time, control and FG coated samples presented higher values of TVB-N and TBA values, followed by samples coated with FG and seaweed extracts (FGC and FGF). Thus, this pattern indicated that a higher quality preservation of tuna coated was achieved with seaweed extracts.

The second principal component (PC 2) accounted for $21.8 \%$ of the total variance. At day 0 , with exception to samples coated with FG and
Codium spp. extract, all treatments presented a similar pattern with respect to $b^{*}$ values. Moreover, it was possible to observe a temporal gradient since the initial pattern of $b^{*}$ was changed by the increase of values for treatments coated with FG (at days 6, 9 and 12), FG and F. vesiculosus extract (day 12) and control samples (day 12). This is an important result since the coating could preserve tuna colour. However, in future it will be important to conduct sensory analysis to confirm if this colour retention is satisfactory to consumers.

\section{Conclusions}

Application of FG EC incorporated with seaweed extracts could be a promising way to extend the shelf life of refrigerated tuna fillets. Incorporation of $F$. vesiculosus extract into FG EC decreased microbial activity, which was reflected in the effect of its application in minimizing TBV$\mathrm{N}$ values and colour changes and consequently increasing shelf-life. These results identified $F$. vesiculosus extract as a potential natural additive to be incorporated in EC formulations to be applied in raw seafood products.

\section{Acknowledgements}

This study had the support of Fundação para a Ciência e Tecnologia (FCT), through the strategic project UID/MAR/04292/2013 granted to MARE.

\section{References}

Ahmad, T., Ismail, A., Ahmad, S. A., Khalil, K. A., Kumar, Y., Adeyemi, K. D., \& Sazili, A. Q. (2017). Recent advances on the role of process variables affecting gelatin yield and characteristics with special reference to enzymatic extraction: a review. Food Hydrocolloids, 63, 85-96. doi:10. 1016/j.foodhyd.2016.08.007 
Alfaro, A. T., Biluca, F. C., Marquetti, C., Tonial, I. B., \& de Souza, N. E. (2014). African catfish (clarias gariepinus) skin gelatin: extraction optimization and physical-chemical properties. Food Research International, 65(C, SI), 416-422. doi:10.1016/j.foodres.2014.05.070

Antoniewski, M. N., Barringer, S. A., Knipe, C. L., \& Zerby, H. N. (2007). Effect of a gelatin coating on the shelf life of fresh meat. Journal of Food Science, 72(6), E382-E387. doi:10.1111/j.1750-3841.2007. 00430.x

Augusto, A., Gil, M., \& Silva, S. (2016). Handbook of seafood: harvesting, quality, protection and health benefits. In E. E. Ã. D. Ismail Yüksel Genç (Ed.), (Chap. Chapter 11 - Packaging technologies and material type for the maintenance of seafood safety. Part III Seafood protection). New York: Nova Science Publishers. Retrieved from https:// www . novapublishers . com / catalog / product_ info $\cdot$ php ? products_id $=59379 \&$ osCsid $=$ eb1f02069466974764d9206b57d02e81

Augusto, A., Simoes, T., Pedrosa, R., \& Silva, S. F. J. (2016). Evaluation of seaweed extracts functionality as post-harvest treatment for minimally processed fuji apples. Innovative Food Science 8 Emerging Technologies, 33, 589-595. doi:10.1016/j.ifset. 2015.10.004

Bjorndal, T., Brasao, A., Ramos, J., \& Tusvik, A. (2016). Fish processing in portugal: an industry in expansion. Marine Policy, 72, 94-106. doi:10.1016/j.marpol.2016.06.011

Blanco-Pascual, N., Montero, M. P., \& GomezGuillen, M. C. (2014). Antioxidant film development from unrefined extracts of brown seaweeds laminaria digitata and ascophyllum nodosum. Food Hydrocolloids, 37, 100-110. doi:10.1016/j.foodhyd.2013. 10.021

Cho, S. M., Gu, Y. S., \& Kim, S. B. (2005). Extracting optimization and physical properties of yellowfin tuna (thunnus albacares) skin gelatin compared to mammalian gelatins. Food Hydrocolloids, 19(2), 221-229. doi:10.1016/j. foodhyd. 2004.05. 005
Duan, J., Cherian, G., \& Zhao, Y. (2010). Quality enhancement in fresh and frozen lingcod (ophiodon elongates) fillets by employment of fish oil incorporated chitosan coatings. Food Chemistry, 119(2), 524-532. doi:10. 1016/j.foodchem.2009.06.055

Etxabide, A., Uranga, J., Guerrero, P., \& de la Caba, K. (2017). Development of active gelatin films by means of valorisation of food processing waste: a review. Food $\mathrm{Hy}$ drocolloids, 68(SI), 192-198. doi:10.1016/j. foodhyd.2016.08.021

FAO. (2016). The state of world fisheries and aquaculture 2016 (SOFIA). Food and Agriculture Organization of the United Nations, Rome 2014. The state of world fisheries and aquaculture. Contributing to food security and nutrition for all. Rome. 200 pp. Retrieved from http://www.fao.org/3/ a-i5555e.pdf

Ghaly, A. E., Dave, D., Budge, S., \& Brooks, M. S. (2010). Fish spoilage mechanisms and preservation techniques. American Journal of Applied Sciences, 7(7), 859-877. doi:10. 3844/ajassp.2010.859.877

Gudmundsson, M. \& Hafsteinsson, H. (1997). Gelatin from cod skins as affected by chemical treatments. Journal of Food Science, 62(1), 37-39. doi:10.1111/j . 1365-2621. 1997.tb04363.x

Haddar, A., Sellimi, S., Ghannouchi, R., Martinez Alvarez, O., Nasri, M., \& Bougatef, A. (2012). Functional, antioxidant and film-forming properties of tunaskin gelatin with a brown algae extract. International Journal of Biological Macromolecules, 51(4), 477-483. doi:10.1016/j. ijbiomac.2012.06.016

Hosseini, S. F., Javidi, Z., \& Rezaei, M. (2016). Efficient gas barrier properties of multilayer films based on poly(lactic acid) and fish gelatin. International Journal of Biological Macromolecules, 92, 1205-1214. doi:10.1016/j.ijbiomac.2016.08.034

Huang, T., Tu, Z.-c., Wang, H., Shangguan, X., Zhang, L., Zhang, N.-h., \& Bansal, N. (2017). Pectin and enzyme complex modified fish scales gelatin: rheological behavior, gel properties and nanostructure. Carbohydrate Polymers, 156, 294-302. 
Jolliffe, I. (2002). Principal component analysis. New York: Springer Verlag. doi:10.1007/ b98835

Kaewdang, O. \& Benjakul, S. (2015). Effect of ethanolic extract of coconut husk on gel properties of gelatin from swim bladder of yellowfin tuna. LWT - Food Science and Technology, 62(2), 955-961. doi:10.1016/ j.lwt.2015.02.006

Karim, A. A. \& Bhat, R. (2009). Fish gelatin: properties, challenges, and prospects as an alternative to mammalian gelatins. Food Hydrocolloids, 23(3), 563-576. doi:10. 1016/j.foodhyd.2008.07.002

Li, T., Hu, W., Li, J., Zhang, X., Zhu, J., \& Li, X. (2012). Coating effects of tea polyphenol and rosemary extract combined with chitosan on the storage quality of large yellow croaker (pseudosciaena crocea). Food Control, 25(1), 101-106. doi:10.1016/j . foodcont.2011.10.029

Lopez-Caballero, M. E., Gomez-Guillen, M. C., Perez-Mateos, M., \& Montero, P. (2005). A chitosan-gelatin blend as a coating for fish patties. Food Hydrocolloids, 19(2), 303311. doi:10.1016/j.foodhyd.2004.06.006

Miranda, J. M., Trigo, M., Barros-Velazquez, J., \& Aubourg, S. P. (2016). Effect of an icing medium containing the alga fucus spiralis on the microbiological activity and lipid oxidation in chilled megrim (lepidorhombus whiffiagonis). Food Control, 59, 290-297. doi:10.1016/j.foodcont.2015.05.034

Mousakhani-Ganjeh, A., Hamdami, N., \& Soltanizadeh, N. (2015). Impact of high voltage electric field thawing on the quality of frozen tuna fish (thunnus albacares). Journal of Food Engineering, 156, 39-44. doi:10.1016/j.jfoodeng.2015.02.004

Nowzari, F., Shabanpour, B., \& Ojagh, S. M. (2013). Comparison of chitosan-gelatin composite and bilayer coating and film effect on the quality of refrigerated rainbow trout. Food Chemistry, 141(3), 1667-1672. doi:10.1016/j.foodchem.2013.03.022

Ojagh, S. M., Rezaei, M., Razavi, S. H., \& Hosseini, S. M. H. (2010). Effect of chitosan coatings enriched with cinnamon oil on the quality of refrigerated rainbow trout. Food
Chemistry, 120(1), 193-198. doi:10.1016/j. foodchem.2009.10.006

Olafsdottir, G., Martinsdottir, E., Oehlenschlager, J., Dalgaard, P., Jensen, B., Undeland, I., ... Nilsen, H. (1997). Methods to evaluate fish freshness in research and industry. Trends in Food Science \& Technology, 8(8), 258-265. doi:10.1016/S09242244(97)01049-2

Pathare, P. B., Opara, U. L., \& Al-Said, F. A.-J. (2013). Colour measurement and analysis in fresh and processed foods: a review. Food and Bioprocess Technology, 6(1), 36-60. doi:10.1007/s11947-012-0867-9

Pinteus, S., Alves, C., Monteiro, H., Araujo, E., Horta, A., \& Pedrosa, R. (2015). Asparagopsis armata and sphaerococcus coronopifolius as a natural source of antimicrobial compounds. World Journal of Microbiology \& Biotechnology, 31(3), 445451. doi:10.1007/s11274-015-1797-2

Pinteus, S., Silva, J., Alves, C., Horta, A., Fino, N., Rodrigues, A. I., .. P Pedrosa, R. (2017). Cytoprotective effect of seaweeds with high antioxidant activity from the peniche coast (portugal). Food Chemistry, 218, 591-599. doi:10.1016/j.foodchem.2016.09.067

Rahman, M. S., Ai-Saidi, G. S., \& Guizani, N. (2008). Thermal characterisation of gelatin extracted from yellowfin tuna skin and commercial mammalian gelatin. Food Chemistry, 108(2), 472-481. doi:10.1016/j. foodchem.2007.10-079

Shyni, K., Hema, G. S., Ninan, G., Mathew, S., Joshy, C. G., \& Lakshmanan, P. T. (2014). Isolation and characterization of gelatin from the skins of skipjack tuna (katsuwonus pelamis), dog shark (scoliodon sorrakowah), and rohu (labeo rohita). Food Hydrocolloids, 39, 68-76. doi:10.1016/j . foodhyd.2013.12.008

Silbande, A., Adenet, S., Smith-Ravin, J., Joffraud, J.-J., Rochefort, K., \& Leroi, F. (2016). Quality assessment of ice-stored tropical yellowfin tuna (thunnus albacares) and influence of vacuum and modified atmosphere packaging. Food Microbiology, 60, 62-72. doi:10.1016/j.fm.2016.06.016

Sinthusamran, S., Benjakul, S., \& Kishimura, H. (2014). Characteristics and gel properties 
of gelatin from skin of seabass (lutes calcarifer) as influenced by extraction conditions. Food Chemistry, 152, 276-284. doi:10 . 1016/j.foodchem.2013.11.109

Tavassoli-Kafrani, E., Shekarchizadeh, H., \& Masoudpour-Behabadi, M. (2016). Development of edible films and coatings from alginates and carrageenans. Carbohydrate Polymers, 137, 360-374. doi:10.1016/j . carbpol.2015.10.074

Ter Braak, C. J. F. \& Smilauer, P. (1998). Canoco reference manual and user's guide to canoco for windows: software for canonical community ordination (version 4). Retrieved from https : / / openlibrary . org / books / OL18268376M / CANOCO_reference_manual_and_user ' s_ guide_to_Canoco_for_Windows

Torrieri, E., Carlino, P. A., Cavella, S., Fogliano, V., Attianese, I., Buonocore, G. G., \& Masi, P. (2011). Effect of modified atmosphere and active packaging on the shelflife of fresh bluefin tuna fillets. Journal of Food Engineering, 105(3), 429-435. doi:10. 1016/j.jfoodeng.2011.02.038

Wahidi, M. E., Amraoui, B. E., Amraoui, M. E., \& Bamhaoud, T. (2015). Screening of antimicrobial activity of macroalgae extracts from the moroccan atlantic coast. Annales Pharmaceutiques Françaises, 73(3), 190196. doi:10.1016/j.pharma.2014.12.005

Wang, T., Jonsdottir, R., Liu, H., Gu, L., Kristinsson, H. G., Raghavan, S., \& Olafsdottir, G. (2012). Antioxidant capacities of phlorotannins extracted from the brown algae fucus vesiculosus. Journal of Agricultural and Food Chemistry, 60(23), 58745883. doi:10.1021/jf3003653

Zar, H. (2010). Biostatistical analysis (N. J. P. E. Limited, Ed.). 
220 | Vala et al.

A Appendix. Supplementary data

IJFS | October 2017 | Volume 6 | pages 201-221 
Table 6: Extraction yield (\% of wet weight) of tuna skin gelatin at different alkali and/or acid pretreatments extraction procedures

\begin{tabular}{cc}
\hline & Yield (\%) \\
\hline $\mathrm{A}$ & 0.41 \\
$\mathrm{~B}$ & 7.87 \\
$\mathrm{C}$ & 0.54 \\
$\mathrm{D}$ & 1.53 \\
$\mathrm{E}$ & 10.28 \\
$\mathrm{~F}$ & 2.54 \\
$\mathrm{G}$ & 26.45 \\
\hline
\end{tabular}

Abbreviations are according to those presented in Table 1

Table 7: Moisture (\%), pH and thiobarbituric acid (TBA; $\mu$ mol malondialdehyde equivalents) values of tuna samples of control (Ct) and coated with fish gelatin (FG), fish gelatin with Codium spp. (FGC) and F. vesiculosus (FGF) extracts solutions during 12 days of storage at $4{ }^{\circ} \mathrm{C}$.

\begin{tabular}{|c|c|c|c|c|c|c|}
\hline & & Day 0 & Day 3 & Day 6 & Day 9 & Day 12 \\
\hline \multirow[t]{4}{*}{ Moisture } & Control & $64.22 \pm 2.95$ & $64.49 \pm 2.82$ & $59.13 \pm 9.27$ & $68.07 \pm 1.72$ & $59.63 \pm 3.51$ \\
\hline & $\mathrm{FG}$ & $69.62 \pm 0.65$ & $64.44 \pm 3.92$ & $61.62 \pm 1.87$ & $62.09 \pm 2.02$ & $61.30 \pm 2.62$ \\
\hline & FGC & $64.85 \pm 4.62$ & $66.82 \pm 4.35$ & $64.49 \pm 3.69$ & $63.54 \pm 2.90$ & $61.82 \pm 2.71$ \\
\hline & FGF & $64.80 \pm 4.79$ & $65.06 \pm 2.23$ & $64.12 \pm 3.50$ & $66.21 \pm 3.18$ & $64.71 \pm 5.59$ \\
\hline \multirow[t]{4}{*}{$\mathrm{pH}$} & Control & $5.75 \pm 0.02$ & $5.70 \pm 0.01$ & $5.68 \pm 0.03$ & $5.80 \pm 0.02$ & $6.03 \pm 0.11$ \\
\hline & FG & $5.75 \pm 0.01$ & $5.69 \pm 0.04$ & $5.69 \pm 0.02$ & $5.68 \pm 0.01$ & $5.73 \pm 0.06$ \\
\hline & FGC & $5.75 \pm 0.05$ & $5.72 \pm 0.06$ & $5.71 \pm 0.02$ & $5.68 \pm 0.02$ & $5.70 \pm 0.03$ \\
\hline & FGF & $5.76 \pm 0.04$ & $5.75 \pm 0.03$ & $5.67 \pm 0.02$ & $5.67 \pm 0.03$ & $5.65 \pm 0.02$ \\
\hline \multirow[t]{4}{*}{ TBA } & Control & $1.16 \pm 0.26$ & $4.96 \pm 1.23$ & $7.37 \pm 0.83$ & $8.46 \pm 0.54$ & $7.44 \pm 1.95$ \\
\hline & $\mathrm{FG}$ & $1.53 \pm 1.07$ & $5.42 \pm 0.89$ & $3.25 \pm 1.16$ & $5.31 \pm 0.81$ & $7.08 \pm 1.43$ \\
\hline & FGC & $1.34 \pm 0.14$ & $8.02 \pm 2.01$ & $8.08 \pm 1.25$ & $7.83 \pm 0.61$ & $8.33 \pm 0.73$ \\
\hline & FGF & $1.05 \pm 0.21$ & $6.87 \pm 0.22$ & $2.60 \pm 0.91$ & $4.46 \pm 0.83$ & $3.99 \pm 0.93$ \\
\hline
\end{tabular}

Table 8: Results of p-value (One-Way ANOVA, LSD post hoc test) when comparing the different extracts solutions (during 12 days of storage at $4{ }^{\circ} \mathrm{C}$ ), namely, control $(\mathrm{Ct})$ and coated with fish gelatin $(\mathrm{FG})$, fish gelatin with Codium spp. (FGC) and F. vesiculosus (FGF) on total volatile basic nitrogen (TVB-N) for tuna samples.

\begin{tabular}{llccccc}
\hline & & $\begin{array}{c}\text { Day 0 } \\
(\mathrm{p})\end{array}$ & $\begin{array}{c}\text { Day 3 } \\
(\mathrm{p})\end{array}$ & $\begin{array}{c}\text { Day 6 } \\
(\mathrm{p})\end{array}$ & $\begin{array}{c}\text { Day 9 } \\
(\mathrm{p})\end{array}$ & $\begin{array}{c}\text { Day 12 } \\
(\mathrm{p})\end{array}$ \\
\hline \multirow{4}{*}{ Control } & FG & 0.677 & 0.504 & 0.461 & 0.102 & $0.007^{*}$ \\
& FGC & 0.703 & $0.026^{*}$ & 0.593 & 0.143 & $0.010^{*}$ \\
& FGF & 0.589 & 0.060 & 0.149 & 0.790 & $0.013^{*}$ \\
\hline \multirow{2}{*}{ FG } & FGC & 0.972 & 0.077 & 0.220 & 0.802 & 0.779 \\
& FGF & 0.900 & 0.174 & 0.435 & $0.046^{*}$ & 0.617 \\
\hline FGC & FGF & 0.871 & 0.607 & 0.063 & 0.068 & 0.823 \\
\hline
\end{tabular}

* The mean difference is significant at the 0.05 level (One-Way ANOVA, LSD post hoc test, p-value $<0.05$ ) 